\title{
УДК 331.103
}

\section{DOI: $10.31732 / 2663-2209-2020-58-103-111$}

\section{МОТИВАЦІЯ ПРАЦІ ТА ПІДВИЩЕННЯ ЕФЕКТИВНОСТІ ДІЯЛЬНОСТІ ПІДПРИЕМСТВА}

\author{
Мотузенко О.В. \\ аспірантка, ВНЗ «Університет економіки та праиі «КРОК», м. Київ, вул. Табірна, 30-32, 03113, Україна, \\ тел.: (066)-096-06-83, e-mail.: Motuzenko@krok.edu.ua, ORCID: https://orcid.org/0000-0003-3434-9553
}

\section{MOTIVATION OF WORK AND INCREASE OF EFFICIENCY OF ACTIVITY OF THE ENTERPRISE}

\author{
Motuzenko O. \\ postgraduate student, "KROK” University, Kyiv, st. Tabirna, 30-32, 03113, Ukraine, tel.: (066)-096-06-83, \\ e-mail.: Motuzenko@krok.edu.ua, ORCID: https://orcid.org/0000-0003-3434-9553
}

\begin{abstract}
Анотація. Світова криза стала найважливішою реальною характеристикою сучасної економічної системи, однією з найбільщ виливових сил, що визначають хід розвитку нашої планети. Вона торкається практично всіх сфер громадського життя, включаючи економіку, політику, ідеологію, соиіальну сферу, культуру, екологію, безпеку, спосіб життя, а також самі умови існування людства. Заради збереження переваги конкурентоспроможних ринків при наявності чітких правил та політичних і географічних кордонів $i$ спрямованості иих перетворень на задоволення потреб людини, управління має ставати більш ефективним $i$ скоординованим. В першу чергу ие стосується управління персоналом, тому що саме людський фактор є одним з визначальних для підприємств в умовах кризи. У статті досліджено мотивацію праиі управлінського персоналу в контексті ефективної діяльності зростання підприємств та організацій. Встановлено, що своєчасне виявлення та діагностування проблемних ситуаџій, що виникають на шляху розвитку $i$ зростання підприємств та організаиій, суттєво залежать від рівня кваліфікаиії та професіоналізму керівника, тобто управліния та мотивація. В рамках розкриття проблематики наукової статті використано дані Свростату (Eurostat). Для опраџювання статистичних даних було застосовано такі методи економічного аналізу як узагальнення і порівняння. Розкриття тематики наукової статті вимагає проведення аналізу таких ключових індикаторів, як рівень зайнятості населення, індекс освіченості населення, індивідуальний рівень иифррових навичок населення, частка осіб, які володіють іноземною мовою (іноземними мовами), частка осіб, цо праиевлачтовані і водночас задоволені своєю роботою (з них частка менеджерів, тобто управліниів). Встановлено, що у краӥнах Свропейського Союзу присутній прийнятний, зокрема високий у Великобританії, Іспанії, Німеччини, Польщі та Франції, рівень задоволеності власною роботою працевлаштованих осіб, у тому числі менеджерів (управліниів).
\end{abstract}

Ключові слова: мотивація, управлінський персонал, підприємство, організація, розвиток.

Формули: 0, рис.: 2, табл.: 3, бібл: 13

Annotation. The global crisis has become the most important real characteristic of the modern economic system, one of the most influential forces that determine the course of development of our planet. It affects virtually all spheres of public life, including economics, politics, ideology, social sphere, culture, ecology, security, lifestyle, as well as the very conditions of human existence. In order to maintain the advantage of competitive markets with clear rules and political and geographical boundaries and to focus these transformations on meeting human needs, governance needs to become more efficient and coordinated. This primarily applies to personnel management, because it is the human factor is one of the determinants of enterprises in a crisis. The article examines the motivation of management staff in the context of effective growth of enterprises and organizations. It has been established that timely identification and diagnosis of problematic situations that arise on the path of development and growth of enterprises and organizations substantially depends on the level of qualification and professionalism of the head, that is, the manager. Eurostat data have been used within the framework of the disclosure of the scientific article. Such methods of economic analysis as generalization and comparison have been applied for processing statistical data. The insight of the scientific article' subject matter requires an analysis of such key indicators as the occupational level, population's education index, individual level of the population's digital skills, the proportion of people who speak a foreign language (foreign languages), the proportion of people employed and at the same time satisfied with their job (of these proportion of the managerial employees, i.e. managers). It has been established that in the countries of European Union, such as: Great Britain, Spain, Germany, Poland and France, there is an acceptable, in particular high level of satisfaction of their own job by employed persons, including managerial employees (managers).

Key words: motivation, management staff, enterprise, organization, development. 
Постановка проблеми. Дослідження світових тенденцій розвитку підприємництва доводить, що для забезпечення зростання підприємств та організацій особливу увагу слід приділити питанням мотивації управлінського персоналу. Водночас, практика функціонування сучасних підприємств та організацій засвідчує, що своєчасне виявлення та діагностування проблемних ситуацій, які складаються на шляху розвитку та зростання безлічі підприємств та організацій у великій мірі залежить від рівня кваліфікації та професіоналізму керівника (управлінця). Своєю чергою, успіх діяльності керівника формується під приводом його вміння поєднувати особисті якості та втілювати їх у процес прийняття управлінських рівень.

Тому, в контексті забезпечення ефективного функціонування та перспективного зростання підприємств та організацій необхідно першочергово вирішити проблемні питання мотивації керівника.

\section{Аналіз останніх досліджень $\boldsymbol{i}$} публікацій. Питання вивчення мотивації персоналу знайшли своє відображення у працях як вітчизняних, так і зарубіжних вчених Т. Базарова, С. Бєлозерова, О. Виханського, В. Воронкової, В. Срьоміна, М. Живко, Є. Ільїна, О. Кузьміна, Н. Любомудрова, П. Мартина, А. Наумова, Ю. Ровенського, Е. Смірнова, Ф. Хедоурі,В.А. Шахового та ін.

В рамках розкриття проблематики наукової статті використано дані Євростату (Eurostat). Для опрацювання статистичних даних було застосовано такі методи економічного аналізу як узагальнення і порівняння.

Формулювання цілей статmі. Метою дослідження аналіз мотивації праці та підвищення ефективності діяльності підприємства.

$\begin{array}{ccr}\text { Виклад } & \text { основного } & \text { матеріалу } \\ \text { дослідження. } & \text { Розкриття } & \text { тематики }\end{array}$

наукової статті вимагає проведення глибокого аналізу відповідних статистичних даних. 3 огляду на, особливу увагу доцільно звернути на огляді та аналізі таких ключових індикаторів, як: рівень зайнятості населення; індекс освіченості населення; індивідуальний рівень цифрових навичок населення; частка осіб, які володіють іноземною мовою (іноземними мовами); частка осіб, що працевлаштовані і водночас задоволені своєю роботою (з них менеджери, у тому числі управлінці).

Аналіз статистичних даних щодо зайнятості населення у країнах Свропейського Союзу продемонстрував досить високий рівень зайнятості населення у таких країнах Свропейського Союзу як Австрія, Великобританія, Данія, Ірландія, Люксембург, Мальта, Нідерланди, Німеччина, Португалія, Угорщина, Чехія та Швеція, рівень зайнятості яких є вищим 72-х \% (табл. 1). На противагу вищезазначеним країнам, найнижчі рівні зайнятості населення спостерігаються у Греції та Латвії, де протягом останніх років відбулося зниження частки зайнятості населення.

Щодо рівня освіченості у країнах Європейського Союзу, то на основі аналізу даних табл. 2, 3'ясовано, що найбільш освіченими країнами, в яких рівень освіченості населення перебуває в межах вище 40-a \%, $є$ такі країни як Великобританія, Ірландія, Кіпр. Натомість, найменш освіченим в період останніх років залишається населення Болгарії, Італії, Мальти, Німеччини, Португалії, Румунії, Словаччини, Угорщини, Хорватії та Чexiï.

Впровадження науково-технічних та інноваційних розробок у діяльність підприємств ставить нові вимоги до своїх працівників та вимагає вміння володіти ними. 
Таблиця 1

Динаміка зміни рівня зайнятості населення (у віці 15-64 роках) у країнах Свропейського Союзу, \%

\begin{tabular}{|c|c|c|c|c|c|c|}
\hline No. & Countries & 2014 & 2015 & 2016 & 2017 & 2018 \\
\hline 1 & Austria & 72,7 & 72,7 & 73,7 & 74,7 & 74,6 \\
\hline 2 & Belgium & 62,6 & 63,2 & 65,2 & 65,8 & 67,2 \\
\hline 3 & Bulgaria & н.Д. & н.д. & н.д. & н.д. & 66,1 \\
\hline 4 & Great Britain & 77,9 & 79,1 & 79,2 & 79,8 & 81,5 \\
\hline 5 & Greece & 53,3 & 56,2 & 54,6 & 54,4 & 52,1 \\
\hline 6 & Denmark & 73,8 & 72,9 & 72,4 & 73,3 & 73,5 \\
\hline 7 & Estonia & 71,7 & 66,8 & 71,8 & 76,4 & 68,4 \\
\hline 8 & Ireland & 65,9 & 67,8 & 70,8 & 72,2 & 74,0 \\
\hline 9 & Spain & 56,6 & 60,3 & 62,0 & 64,1 & 65,8 \\
\hline 10 & Italy & 60,1 & 60,8 & 61,0 & 61,3 & 61,6 \\
\hline 11 & Cyprus & 65,6 & 65,4 & 67,1 & 69,6 & 67,7 \\
\hline 12 & Latvia & 62,3 & 62,1 & 75,7 & 63,8 & 56,8 \\
\hline 13 & Lithuania & 76,7 & 57,2 & 66,9 & 72,6 & 70,2 \\
\hline 14 & Luxembourg & 74,0 & 71,8 & 71,7 & 73,6 & 74,6 \\
\hline 15 & Malta & 75,9 & 75,8 & 78,7 & 79,7 & 80,4 \\
\hline 16 & Netherlands & 72,4 & 71,5 & 74,0 & 75,4 & 74,7 \\
\hline 17 & Germany & н.д. & н.д. & н.д. & 77,6 & 78,6 \\
\hline 18 & Poland & 64,2 & 69,7 & 61,4 & 67,8 & 70,6 \\
\hline 19 & Portugal & 73,8 & 75,1 & 76,7 & 80,3 & 80,9 \\
\hline 20 & Romania & н.д. & н.д. & н.д. & Н.Д. & н.д. \\
\hline 21 & Slovakia & 64,4 & 55,5 & 62,3 & 68,3 & 68,3 \\
\hline 22 & Slovenia & 56,9 & 60,0 & 59,7 & 65,4 & 69,7 \\
\hline 23 & Hungary & 72,5 & 70,5 & 76,9 & 76,4 & 74,3 \\
\hline 24 & Finland & 72,4 & 70,1 & 71,2 & 71,5 & 71,9 \\
\hline 25 & France & 66,9 & 65,9 & 65,6 & 67,3 & 68,9 \\
\hline 26 & Croatia & 57,1 & 61,0 & 64,5 & 70,6 & 71,6 \\
\hline 27 & Czech Republic & 69,2 & 68,5 & 72,6 & 78,4 & 77,6 \\
\hline 28 & Sweden & 74,9 & 75,7 & 76,5 & 77,7 & 79,1 \\
\hline
\end{tabular}

Джерело: Eurostat

Таблиця 2

Динаміка зміни індексу освіченості населення (у віці 15-64 роках) у країнах

Свропейського Союзу, \%

\begin{tabular}{|l|l|l|l|l|l|l|l|}
\hline No. & \multicolumn{1}{|c|}{ Countries } & 2014 & 2015 & 2016 & 2017 & 2018 & 2019 \\
\hline 1 & Austria & 27,4 & 28,1 & 28,9 & 29,7 & 30,1 & 31,0 \\
\hline 2 & Belgium & 32,6 & 32,7 & 33,2 & 35,6 & 36,0 & 36,2 \\
\hline 3 & Bulgaria & 23,6 & 24,1 & 24,4 & 24,5 & 24,8 & 24,7 \\
\hline 4 & Great Britain & 36,6 & 37,6 & 38,3 & 38,7 & 39,3 & 40,2 \\
\hline 5 & Greece & 24,6 & 25,4 & 26,4 & 27,2 & 27,7 & 27,8 \\
\hline 6 & Denmark & 29,4 & 30,2 & 30,9 & 32,1 & 32,4 & 32,8 \\
\hline 7 & Estonia & 32,6 & 33,3 & 34,1 & 34,7 & 35,9 & 36,2 \\
\hline 8 & Ireland & 38,0 & 39,0 & 39,5 & 40,4 & 40,5 & 40,7 \\
\hline 9 & Spain & 31,7 & 32,1 & 32,7 & 33,2 & 34,0 & 34,9 \\
\hline 10 & Italy & 15,0 & 15,5 & 15,7 & 16,5 & 17,1 & 17,3 \\
\hline 11 & Cyprus & 36,4 & 36,4 & 37,6 & 38,1 & 39,4 & 40,2 \\
\hline 12 & Latvia & 26,9 & 28,1 & 29,5 & 30,0 & 30,1 & 30,7 \\
\hline 13 & Lithuania & 31,4 & 33,2 & 34,1 & 34,8 & 36,1 & 37,4 \\
\hline 14 & Luxembourg & 39,6 & 35,2 & 34,1 & 34,8 & 36,1 & 37,4 \\
\hline 15 & Malta & 19,4 & 19,9 & 20,3 & 22,1 & 24,6 & 25,7 \\
\hline 16 & Netherlands & 29,7 & 30,5 & 31,0 & 32,1 & 33,0 & 33,8 \\
\hline 17 & Germany & 23,2 & 23,8 & 24,4 & 24,8 & 25,2 & 25,7 \\
\hline 18 & Poland & 23,8 & 24,4 & 25,2 & 26,3 & 27,2 & 28,0 \\
\hline 19 & Portugal & 19,7 & 20,7 & 21,5 & 21,7 & 22,5 & 23,6 \\
\hline 20 & Romania & 14,2 & 15,0 & 15,1 & 15,3 & 15,5 & 15,9 \\
\hline
\end{tabular}




\begin{tabular}{|l|l|l|l|l|l|l|l|}
\hline 21 & Slovakia & 18,1 & 18,9 & 19,7 & 20,7 & 22,0 & 23,0 \\
\hline 22 & Slovenia & 25,1 & 26,6 & 27,2 & 28,7 & 28,7 & 29,1 \\
\hline 23 & Hungary & 20,2 & 20,9 & 20,6 & 20,9 & 21,7 & 22,4 \\
\hline 24 & Finland & 34,7 & 35,5 & 35,9 & 36,4 & 37,3 & 38,3 \\
\hline 25 & France & 29,8 & 30,4 & 30,9 & 31,4 & 32,8 & 33,4 \\
\hline 26 & Croatia & 18,5 & 19,7 & 20,0 & 20,6 & 22,0 & 22,4 \\
\hline 27 & Czech Republic & 19,1 & 19,8 & 20,6 & 21,4 & 21,7 & 21,5 \\
\hline 28 & Sweden & 32,8 & 34,0 & 35,3 & 36,0 & 37,1 & 37,6 \\
\hline
\end{tabular}

Джерело: Eurostat

3 огляду на те, неупинно повинна зростати частка населення, які володіють інформацією про сучасні науково-технічні та інноваційні розробки та вміють ними користуватись.

Відтак, протягом 2016-2019 рр. суттєво висока частка населення, які володіють цифровими навичками, була присутня у таких країнах Європейського Союзу, як Австрія, Бельгія, Великобританія, Данія, Естонія, Люксембург, Нідерланди, Німеччина, Фінляндія, Чехія та Швеція. Натомість, низький індивідуальний рівень цифрових навичок мало населення Болгарії та Румунії (табл. 3).

Таблиця 3

Динаміка зміни індивідуального рівня цифрових навичок населення у країнах

Свропейського Союзу, \% осіб

\begin{tabular}{|c|c|c|c|c|c|c|}
\hline No. & Countries & 2015 & 2016 & 2017 & 2018 & 2019 \\
\hline 1 & Austria & 64 & 65 & 67 & н.д. & 66 \\
\hline 2 & Belgium & 60 & 61 & 61 & н.д. & 61 \\
\hline 3 & Bulgaria & 31 & 26 & 29 & н.д. & 29 \\
\hline 4 & Great Britain & 67 & 69 & 71 & н.д. & 74 \\
\hline 5 & Greece & 44 & 46 & 46 & н.д. & 51 \\
\hline 6 & Denmark & 75 & 78 & 71 & н.д. & 70 \\
\hline 7 & Estonia & 65 & 60 & 60 & н.д. & 62 \\
\hline 8 & Ireland & 44 & 44 & 48 & н.д. & 53 \\
\hline 9 & Spain & 54 & 53 & 55 & н.д. & 57 \\
\hline 10 & Italy & 43 & 44 & н.д. & н.д. & 42 \\
\hline 11 & Cyprus & 43 & 43 & 50 & н.д. & 45 \\
\hline 12 & Latvia & 49 & 50 & 48 & н.д. & 43 \\
\hline 13 & Lithuania & 51 & 52 & 55 & н.д. & 56 \\
\hline 14 & Luxembourg & 86 & 86 & 85 & н.д. & 65 \\
\hline 15 & Malta & 53 & 50 & 57 & н.д. & 56 \\
\hline 16 & Netherlands & 72 & 77 & 79 & н.д. & 79 \\
\hline 17 & Germany & 67 & 68 & 68 & н.Д. & 70 \\
\hline 18 & Poland & 40 & 44 & 46 & н.д. & 44 \\
\hline 19 & Portugal & 48 & 48 & 50 & н.Д. & 52 \\
\hline 20 & Romania & 26 & 28 & 29 & н.д. & 31 \\
\hline 21 & Slovakia & 53 & 55 & 59 & н.д. & н.д. \\
\hline 22 & Slovenia & 51 & 53 & 54 & н.д. & 55 \\
\hline 23 & Hungary & 50 & 51 & 50 & н.д. & 49 \\
\hline 24 & Finland & 74 & 73 & 76 & н.д. & 76 \\
\hline 25 & France & 57 & 56 & 57 & н.д. & 57 \\
\hline 26 & Croatia & 51 & 55 & 41 & н.Д. & 53 \\
\hline 27 & Czech Republic & 57 & 54 & 60 & н.д. & 62 \\
\hline 28 & Sweden & 72 & 69 & 77 & н.д. & 72 \\
\hline
\end{tabular}

Джерело: Eurostat

В період останніх років спостерігається зростання частки осіб серед населення країн Свропейського Союзу, яке володіє іноземною мовою. Як і 2011 році, так і 2016 році, значна частка осіб серед населення країн Свропейського Союзу була присутня у таких країнах як Болгарія, Великобританія, Ірландія, Португалія, Румунія та Угорщина (рис. 1). 


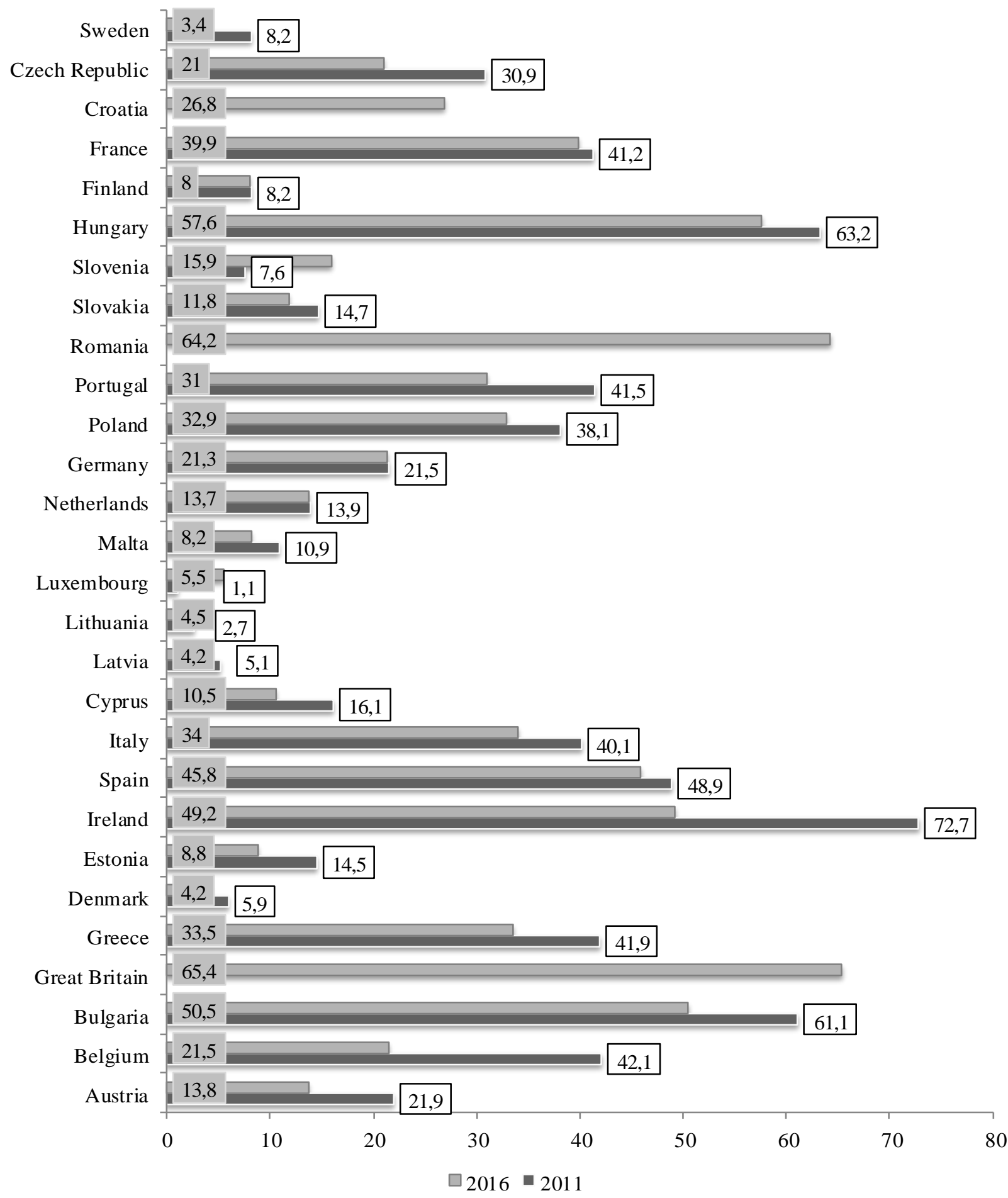

Рис. 1. Частка осіб серед населення країн Свропейського Союзу, що володіс іноземною мовою, \%

Джерело: Eurostat

Аналіз динаміки задоволеності власною роботою працевлаштованих осіб показав, що дуже задоволеним $\epsilon$ населення Великобританії, Іспанії, Німеччини, Польщі та Франції (рис. 2). Поряд 3 тим, частка задоволених роботою, зокрема i посадою менеджерів (управлінців) із загальної кількості задоволених осіб $\epsilon$ висока у Великобританії, Німеччині та Франції. 


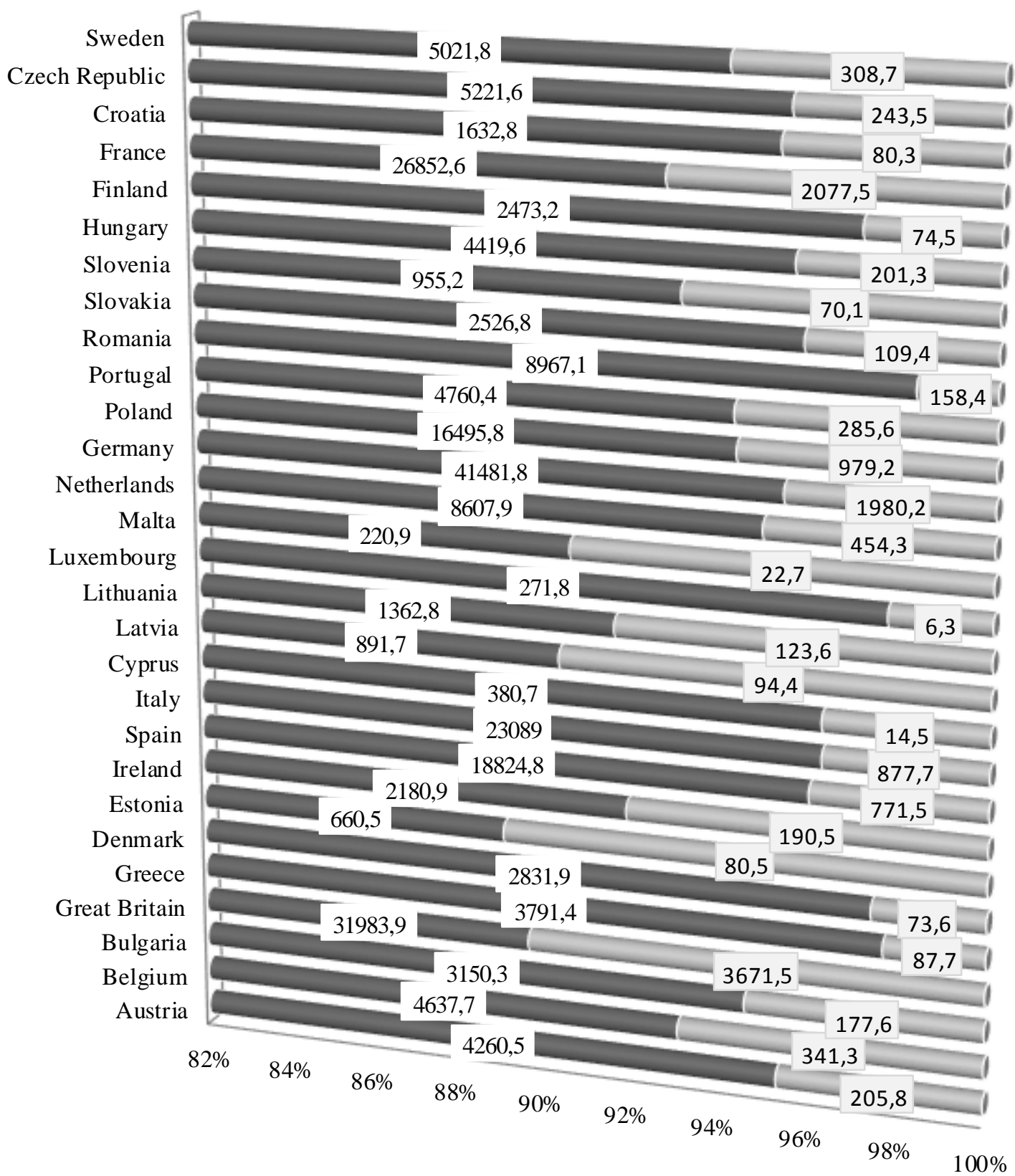

- Кількість працевлаштованих осіб, що задоволені роботою, тис. осіб

च 3 них менеджери (управлвнський персонал)

\section{Рис. 2. Динаміка кількості працевлаштованих працівників, що задоволені роботою у 2017 році, тис. осіб}

Джерело: Eurostat

Таким чином, на основі проведеного аналізу таких показників як рівень зайнятості населення, індекс освіченості населення, індивідуальний рівень цифрових навичок населення, частка осіб, які володіють іноземною мовою (іноземними мовами), частка осіб, що працевлаштовані і водночас задоволені своєю роботою (з них менеджери, у тому числі управлінці) доцільно зауважити, що позитивні тенденції цих показників відбуваються у багатьох країнах Європейського Союзу.

Стає зрозумілим той факт, що одним із шляхів покращення вищезазначених показників $є$ саме мотивація, яку 
проявляють на підприємствах та організаціях до працівників та управлінців. Огляд та аналіз статистичних даних показав, що в багатьох країнах Європейського Союзу мотивація виступає одним із елементів забезпечення успішності діяльності підприємств та організації. Про це саме засвідчує високий рівень задоволеності власною роботою працевлаштованих осіб, у тому числі менеджерів (управлінців).

Огляд літератури

Ключові засади мотивації управлінського персоналу в контексті забезпечення зростання підприємств та організацій представлені у дослідженнях багатьох провідних світових науковців.

Відтак, Delmar F. та Wiklund J. (2008) досліджено вплив мотивації на кар'єрний ріст менеджера. Окрім того, науковці дійшли висновку, що промотивований менеджер ефективно управляє діяльністю підприємства, i, тим самим, впливає на покращення результатів ведення бізнесу (Delmar, F., Wiklund, J., 2008).

Gillan S. L., Hartzell J. C., Koch A. та Starks L. T. (2010) проаналізовано особливості мотивації трудової діяльності на підприємствах, що функціонують в екологічній, соціальній та управлінській сферах. За результатами аналізу науковці дійшли висновку, що менеджери, у тому числі управлінці, на відміну від акціонерів підприємства більш бережливо ставляться до цінностей, зокрема i витрат підприємства, незважаючи на те, що рівень ïx зарплат $\epsilon$ значно нижчим за зарплати акціонерів (Gillan, S. L., Hartzell, J. C., Koch, A., Starks, L. T., 2010).

Натомість, Maslen S. та Hopkins A. (2014) досліджено особливості мотивації менеджерів, що працюють на підприємствах, які віднесено до небезпечних сфер діяльності. Відтак, науковцями визначено роль стимулів, що призначені для управління рядом великих ризиків можливого виникнення аварій у небезпечних сферах діяльності. Встановлено, що мотивувати менеджерів потрібно не лише задля отримання ділових i фінансових результатів від діяльності підприємства, але і з метою забезпечення безпеки цієї діяльності в контексті запобігання виникненню різного роду аварій (Maslen, S., Hopkins, A., 2014).

Ke W., Tan, C-H., Choon-Ling S. тaKwok-Kee W. (2012) вважають. що внутрішню мотивацію менеджерів на підприємстві можуть викликати два важелі:

1) автономне проектування робочих місць;

2) тактика соціалізації.

У дослідженні науковці доводять також i те, що внутрішня мотивація проявляється через нормативну (спонукає до думки, що технологія дозволяє отримати ряд зовнішніх вигод, а саме: виконання завдань, підвищення рівня продуктивності праці) та гедонічну (забезпечує отримання задоволення від використання технологій) мотивацію (Ke, W., Tan, C-H., Choon-Ling, S., Kwok-Kee, W., 2012).

Rusetski A. (2011) досліджено культурні і процесуальні фактори, які чинять вплив на мотивування керівників підприємств. У ході дослідження встановлено, що важливим чинником, який знижує рівень мотивації менеджера виступає стратегічна орієнтація технологій. Натомість, орієнтація на клієнтів підприємства та культурне ігнорування класичних принципів менеджменту лише посилюють мотивацію менеджерів. За висновками науковця, ефективнішим у мотивації менеджерів залишається все-таки вплив культурних факторів, ніж здійснення відповідного оцінювання діяльності менеджера чи надання йому компенсацій (Rusetski, A., 2011).

Поряд 3 тим, Chromjakova F. (2016) представилено основні критерії мотивації, якими повинен володіти управлінець, зокрема це:

1) цілеспрямоване зосередження на досягненні цілей та реалізації мети функціонування підприємства;

2) прийняття виважених та обгрунтованих управлінських рішень;

3) хороші взаємовідносини із колективом; 
4) творче мислення та інноваційні підходи до вирішення поставлених завдань тощо (Chromjakova, F., 2016).

В рамках зазначеного вище, Li Q. (2015) вважає, що стимулювання керівника підприємства необхідно проводити за принципом теорії надзвичайних ситуацій. Своєю чергою, використання того чи іншого стимулу для керівника першочергово має залежати від того, який рівень освіченості керівника та чи $\epsilon$ керівник високоякісним кадром. Поряд 3 тим, дослідження $\mathrm{Li} \mathrm{Q}$. засвідчили, що зазвичай керівник в якості стимулу хоче бачити незалежність власних можливостей, тоді як попит на фінансові стимули є не настільки важливим (Li, Q., 2015).

Laura L. Paglis та Stephen G. Green (2002) розроблено модель лідерства, яка базується на критеріях мотивації менеджерів до досягнення ними лідерських позицій на підприємстві. Основними елементами цього процесу виступають:

1) визначення перспективного напрямку подальшої діяльності менеджера;

2) посилення позиції прихильників менеджера;

3) усунення наявних та потенційних перешкод, що виникають на шляху зміцнення лідерських позицій (Laura, L. Paglis, Stephen, G. Green, 2002).

Разом 3 тим, Schmid Mast M., Hall J. A. та Schmid P. С. (2010) заявляють, що одним із ключових елементів ефективності лідерських позицій керівника виступає його силова мотивація, яка безпосередньо пов'язана із домінуванням менеджера як особистості (Schmid Mast, M., Hall, J. A., Schmid, P. C., 2010).

Водночас, Wziatek-Stasko A. (2016) зауважує, що мотивація менеджерів виступає ключовим індикатором визначення якості їх лідерства (WziatekStasko, A., 2016).

В контексті розкриття тематики наукової статті, слід відмітити, що Buble M., Juras A., та Matic I. (2014) здійснено аналіз взаємозв'язку між стилем керівництва, який використовується на підприємстві, і мотивацією керівника, яка спонукає його до досягнення мети та цілей діяльності підприємства. У ході дослідження науковці дійшли висновку, що зайняття менеджером позиції у вищих ланках системи управління підприємством вимагає наявності у менеджера значного досвіду роботи (принаймні 10-15 років) та необхідного рівня освіти. Попри те, було встановлено, що мотивація управлінського персоналу поділяється на дві частини:

- внутрішня мотивація, яка відображає способи спонукання до діяльності менеджера відповідно до складності його роботи;

- зовнішня мотивація, через способи спонукання якої відображається рівень задоволеності менеджера власними умовами праці та заробітною платою (Buble, M., Juras, A., Matic, I., 2014).

Своєю чергою, Decoene V. та Bruggeman W. (2006) досліджено взаємозв'язок стратегічного вимірювання, мотивації (у тому числі розроблених певних мотиваційних механізмів) i організаційної ефективності керівника підприємства в рамках використання збалансованої системи показників. Результати проведеного науковцями дослідження дають можливість отримати інформацію про те, як може підприємство покращити результати діяльності. Разом 3 тим, з'ясовано, що ефективне стратегічне вимірювання не лише мотивує керівника, але i вимагає його безпосередню та активну участь у процесах діяльності підприємства (Decoene, V., Bruggeman, W., 2006).

Висновки. За результатами проведеного огляду та аналізу теоретичних та практичних аспектів застосування мотивації до працівників, зокрема і до управлінського персоналу на підприємствах та організаціях країн Свропейського Союзу, встановлено, що у цих країнах присутній прийнятний, зокрема високий у Великобританії, Іспанії, Німеччини, Польщі та Франції, рівень задоволеності власною роботою працевлаштованих осіб, у тому числі менеджерів (управлінців). 
Дослідження доводять, що своєчасне виявлення та діагностування проблемних ситуацій, які виникають на шляху розвитку i зростання підприємств та організацій, суттєво залежить від рівня кваліфікації та професіоналізму керівника, тобто управлінця.

\section{תimepamypa:}

1. Buble, M. Juras, A. and Matic, I. (2014), "The relationship between managers' leadership styles and motivation", Management, №19, p. 161-193.

2. Chromjakova, F. (2016), "The Key Principles of Process Manager Motivation in Production and Administration Processes in an Industrial Enterprise", Journal of Competitiveness, №8(1), p. 95-110. DOI: 10.7441/joc.2016.01.07.

3. Decoene, V. and Bruggeman, W. (2006), "Strategic alignment and middle level managers' motivation in a balanced scorecard setting", International Journal of Operations \& Production Management, №26(4), p. 429-448. https://doi.org/10.1108/01443570610650576.

4. Delmar, F. and Wiklund, J. (2008), "The Effect of Small Business Managers' Growth Motivation on Firm Growth: A Longitudinal Study", Entrepreneurship Theory and Practice, №32(3), p. 437-457.

5. Eurostat. URL: https://ec.europa.eu/eurostat/.

6. Gillan, S. L. Hartzell, J. C. Koch, A. and Starks, L. T. (2010), "Firms' Environmental, Social and Governance (ESG) Choices, Performance and Managerial Motivation", Unpublished working paper, 10. URL: https://www.researchgate.net/profile/Maretno_Harjoto/ publication/265849879_Board_Diversity_and_Corpora te_Social_Responsibility/links/56024b2e08aeb30ba735 5cda.pdf.
7. Ke, W. Tan, C-H. Choon-Ling, S., Kwok-Kee, W. (2012), "Inducing Intrinsic Motivation to Explore the Enterprise System: The Supremacy of Organizational Levers", Journal of Management Information Systems, №29(3), p. 257-290. DOI : https://doi.org/10.2753/MIS0742-1222290308.

8. Laura, L. Paglis, Stephen, G. Green (2002), "Leadership self efficacy and managers' motivation for leading change", Journal of Organizational Behavior, №23(2), p. 215-235. https://doi.org/10.1002/job.137.

9. Li, Q. (2015), "The Discussion of Theory Review and Practice on Enterprise Executives Incentive", Journal of Human Resource and Sustainability Studies, №3(1), p. 51-55. DOI: 10.4236/jhrss.2015.31008.

10. Maslen, S. and Hopkins, A. (2014), "Do incentives work? A qualitative study of managers' motivations in hazardous industries", Safety Science, №70, p. $419-428$. https://doi.org/10.1016/j.ssci.2014.07.008.

11. Rusetski, A. (2011), "Getting Proactive: Cultural And Procedural Drivers Of Managerial Motivation To Act", Journal of Business \& Economics Research, № 9(1), p. 111-120.

12. Schmid Mast, M., Hall, J. A., Schmid, P. C. (2010), "Wanting to Be Boss and Wanting to Be Subordinate: Effects on Performance Motivation", Journal of Applied Social Psychology, №40 (2), p. 458-472. DOI : 10.1111/j.1559-1816.2009.00582.x.

13. Wziatek-Stasko, A. (2016), "The extent of managers' motivation as a determinant of leadership quality", Economics and Management, №8(1), p. 3746. DOI: 10.1515/emj-2016-0004.

Стаття надійшла до редакції 12.05.2020 р. 